\title{
Dilemas da visualidade jornalística das violências contra pessoas LGBTQ+ e contra mulheres heterossexuais no Brasil
}

\author{
Dilemmas of journalistic visibility of violence against LGBTQ+ people and \\ against heterosexual women in Brazil \\ Dilemas de la visualidad periodística de las violencias contra personas \\ LGBTQ+ y contra mujeres heterosexuales en Brasil
}

Bruno Souza Leal ${ }^{1, a}$

brunosleal@gmail.com | http://orcid.org/o000-0002-6937-6976

Carlos Camargos Mendonça ${ }^{1, b}$

macomendonca@gmail.com | http://orcid.org/o000-0002-4883-3410

${ }^{1}$ Universidade Federal de Minas Gerais, Faculdade de Filosofia e Ciências Humanas. Belo Horizonte, MG, Brasil.

a Doutorado em Estudos Literários pela Universidade Federal de Minas Gerais.

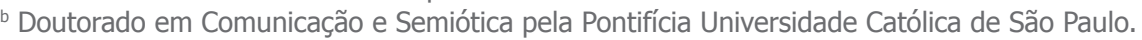

\section{Resumo}

Nos textos jornalísticos, chama a atenção a diferença entre as imagens de casos de violência contra a mulher cisgênero e heterossexual e as contra pessoas LGBTQ+. Tratando-se das pessoas LGBTQ+, as imagens costumam ser brutais, com exposição de sangue e de corpos feridos por armas diversas. Já a cobertura de casos de violência contra a mulher cis e heterossexual é diametralmente oposta: as imagens tendem a ser pouco contundentes, muitas vezes mostrando paisagens de lugares onde ocorreram os crimes, em alguns casos mostrando os rostos de agressores e vítimas, nunca cenas de sangue ou corpos com marcas de agressão. Neste artigo, tomamos a instabilidade textual como ponto de partida para refletirmos sobre o contraste entre os modos de tratamento jornalístico conferidos no Brasil a essas duas violências e o que impacta no entendimento acerca das relações que conformam a visualidade e a cultura visual.

Palavras-chave: Violência; LGBTQ+; Mulheres; Cultura visual; Jornalismo; Minorias sexuais e de gênero; Gênero. 


\begin{abstract}
In Brazilian journalistic texts, the difference between the images of cases of violence against cis and heterosexual women and those against LGBTQ+ people are astonishing. In the case of LGBTQ+ people, the images are usually brutal, with exposure of blood and bodies injured by various weapons. The coverage of cases of violence against cis and heterosexual women is the opposite: the images tend to be inconclusive, often showing landscapes of places where crimes occurred, sometimes showing the faces of perpetrators and victims and never scenes of blood or bodies with marks of aggression. In this article, we take the textual instability as a starting point to reflect on the contrast between the ways of journalistic treatment in Brazil conferred to these two violences and what impacts on the understanding about the relations that conform the visuality and the visual culture.
\end{abstract}

Keywords: Violence; LGBTQ+; Women; Visual culture; Journalism; Sexual and gender minorities; Gender.

\title{
Resumen
}

En los textos periodísticos, llama la atención la diferencia entre las imágenes de casos de violencia contra la mujer cis heterosexual y las contra personas LGBTQ+. Tratándose de las personas LGBTQ+, las imágenes suelen ser brutales, con exposición de sangre y de cuerpos heridos por armas diversas. La cobertura de casos de violencia contra la mujer cis heterosexual es diametralmente opuesta: las imágenes tienden a ser poco contundentes, muchas veces mostrando paisajes de lugares donde ocurrieron los crímenes, en algunos momentos mostrando los rostros de agresores y víctimas y nunca escenas de sangre o cuerpos con marcas de agresión. En este artículo tomamos la inestabilidad textual como punto de partida para reflexionar sobre el contraste entre los modos de tratamiento periodístico en Brasil conferidos a esas dos violencias y lo que impacta en el entendimiento acerca de las relaciones que conforman la visualidad y la cultura visual.

Palabras-clave: Violencia; LGBTQ+; Mujeres; Cultura visual; Periodismo; Minorías sexuales y de género; Género.

Este texto compõe o dossiê 40 anos do movimento LGBT no Brasil: comunicação, saúde e direitos humanos.

Contribuição dos autores:

Concepção e desenho do estudo: Bruno Souza Leal; Carlos Camargos Mendonça.

Aquisição, análise ou interpretação dos dados: Bruno Souza Leal; Carlos Camargos Mendonça.

Redação do manuscrito: Bruno Souza Leal; Carlos Camargos Mendonça.

Revisão crítica do conteúdo intelectual: Bruno Souza Leal; Carlos Camargos Mendonça.

Declaração de conflito de interesses: não há conflito de interesses.

Fontes de financiamento: Coordenação de Aperfeiçoamento de Pessoal de Nível Superior (Capes), Conselho Nacional de Desenvolvimento Científico e Tecnológico (CNPq) e Fundação de Amparo à Pesquisa do Estado de Minas Gerais (Fapemig).

Considerações éticas: não há.

Agradecimentos/Contribuições adicionais: não há.

Histórico do artigo: submetido: 31 jan. 2019 | aceito: 10 maio 2019 | publicado: 28 jun. 2019.

Apresentação anterior: não há.

Licença CC BY-NC atribuição não comercial. Com essa licença é permitido acessar, baixar (download), copiar, imprimir, compartilhar, reutilizar e distribuir os artigos, desde que para uso não comercial e com a citação da fonte, conferindo os devidos créditos de autoria e menção à Reciis. Nesses casos, nenhuma permissão é necessária por parte dos autores ou dos editores. 


\section{Introdução}

Nos últimos anos, vimos conduzindo diferentes pesquisas ${ }^{i}$ que abordam o tratamento midiático brasileiro da violência contra a mulher (cisgênero ${ }^{\text {ii }}$, transgênero, heterossexual e homossexual) e contra pessoas LGBT (Lésbicas, Gays, Bissexuais, Travestis, Transexuais e Transgêneros). Nessas pesquisas, reunimos um corpus vasto e heterogêneo de imagens midiáticas, oriundas de produtos jornalísticos - em especial jornais diários, portais da internet e hemerotecas virtuais -, textos publicitários, produtos ficcionais, entre outros. Nos textos jornalísticos, chama a atenção a diferença entre as imagens de casos de violência contra a mulher cis e heterossexual e as contra pessoas LGBTQ+ (Lésbicas, Gays, Bissexuais, Transgêneros e Queer). Tratando-se das pessoas LGBTQ+, as imagens costumam ser brutais, com exposição de sangue e de corpos feridos por armas diversas. Já a cobertura de casos de violência contra a mulher cis e heterossexual é diametralmente oposta: as imagens tendem a ser pouco contundentes, muitas vezes mostrando paisagens de lugares onde ocorreram os crimes, expondo, eventualmente, os rostos de agressores e vítimas e nunca cenas de sangue ou corpos com marcas de agressão. Essa diferença de tratamento imagético nos é particularmente interessante, não apenas naquilo que explicitam as diferentes tensões que perpassam as violências contra a mulher e contra pessoas LGBTQ+. Ela permite, por exemplo, reconhecer distintos e complementares movimentos de colonização do imaginário ${ }^{1}$, a partir de uma reflexão tanto sobre as dinâmicas de visualidade quanto sobre a instabilidade pragmática dos textuais visuais.

Os cerca de 900 textos verbo-visuais analisados foram coletados, nas pesquisas referidas, entre os anos de 2015 e 2017. A coleta documental considerou publicações em jornais tradicionais e populares em versões on-line e off-line. Neste artigo, operamos com um recorte desse vasto material, recuperando o tratamento da violência em mídias informativas. Foram consultados os jornais impressos que circulam na cidade de Belo Horizonte e versões digitalizadas arquivadas na hemeroteca virtual do Grupo Gay da Bahiaiii. Consultamos sítios jornalísticos com associados aos jornais. A partir da leitura dos textos foram investigados diferentes aspectos editoriais e elementos textuais, como os tipos de ocorrência, a localidade, as espacialidades (público/privado); as relações de proximidade ou não entre pessoa agressora e pessoa agredida; o tipo de nominação pela cobertura jornalística dos atos criminosos; o tratamento conferido no texto aos criminosos e às vítimas; bem como as partes violentadas dos corpos. Agrupamos as notícias por região, dividimos as regiões por estados e cidades, além de consideramos o dia da semana e o ambiente onde se passou o evento. Uma análise geral da coleta revelou um dado significativo: é recorrente a cobertura jornalística de casos diversos de violência, com privilégio aos assassinatos, que são sofridos por mulheres cis e heterossexuais e por pessoas LGBTQ+, mas essa emergência regular e cotidiana se dá sem que o componente de gênero e de LGBTfobia seja explicitado nas narrativas. Há, portanto, nessa cobertura, uma complexa relação de visibilidade e invisibilidade que desafia entendimentos apressados. A violência contra mulheres cis e heterossexuais e pessoas LGBTQ+ é simultaneamente presente e ausente, visível e invisível nos jornais pesquisados, uma tensão da qual buscamos, aqui, indicar alguns contornos.

Neste artigo, não nos propomos a uma análise nem exaustiva nem totalizante sobre os modos como as violências contra LGBTQ+ e contra mulheres cis e heterossexuais são apresentadas no jornalismo brasileiro. Tomamos alguns poucos exemplos retirados dos corpora de pesquisas dedicadas a esses temas

\footnotetext{
i 'Narrativas de um problema cotidiano: a violência de gênero e o testemunho jornalístico'. Financiadores: Fundação de Amparo à Pesquisa do Estado de Minas Gerais (Fapemig)/Conselho Nacional de Desenvolvimento Científico e Tecnológico (CNPq). 'Corpos feitos textos visuais: as narrativas de si como estratégia de resistência'. Financiadores: CNPq/Fapemig.

ii Nota de revisão (NR): Conforme registro no Dicionário Houaiss da Língua Portuguesa, cisgênero é "adj. s.2g. diz-se de ou gênero de percepção de identidade em que o indivíduo, por suas experiências de vida, aceita como verdadeiro o sexo que lhe foi atribuído ao nascer." https://houaiss.uol.com.br/pub/apps/www/v3-3/html/index.php\#1. A equipe da Reciis manteve a opção dos autores pela redução cis, muito comum em língua inglesa, apesar de ainda não dicionarizada em português.

iii Disponível em: https://homofobiamata.wordpress.com/.
} 
para explorar possibilidades de articulação entre violência e imaginário, a partir de um referencial teórico específico. Na reflexão que procuramos desenvolver, tomamos a instabilidade textual como ponto de partida para refletirmos sobre o contraste entre os modos de tratamento jornalístico conferidos no Brasil, a essas duas violências, e o que impacta no entendimento acerca da visualidade. As páginas de jornais e portais da internet sobre as quais nos debruçamos são por nós compreendidas como textos verbovisuais: compostos por múltiplos sistemas semióticos, integrando elementos verbais e visuais a fim de complexificar as maneiras pelas quais são produzidos estímulos, percepções e significados. Entendemos que, neste tipo de texto, as unidades de comunicação estão dispostas em uma trama heterogênea, sustentada em práticas discursivas e culturais múltiplas. Dessa maneira, os modos de leitura ocorrem sob certas condições interpretativas, convencionadas cultural e politicamente. Gonzalo Abril ${ }^{2}$, afastado de uma perspectiva que entende a visualidade como algo imanente ao visual e próximo de um ponto de vista político da cultura visual, sublinha que ela é um somatório da percepção visual com as experiências visuais vividas e conceituadas. A partir desse momento, então, passamos a adotar a terminologia estabelecida por Abrilil-3 para desenvolvermos o percurso reflexivo que propomos.

\section{Um olhar sobre a cultura visual}

Abril $^{2-3}$ prefere a expressão 'texto visual' para designar o que comumente chamamos de imagem, ou seja, o produto imagético que resulta de processos técnicos diversos - como a pintura, a fotografia, a câmera audiovisual etc. Preocupado em apreender metodológica e conceitualmente a cultura visual e os processos sociais de visualidade, Abril, por um lado, entende que a compreensão do termo 'imagem' como uma espécie de contração da expressão 'imagem técnica' é uma redução indesejável e uma abstração, uma vez que não encontra amparo nas dinâmicas sociais historicamente situadas. Por outro, cunha então uma terminologia calcada numa revisão da ideia de texto e na articulação da imagem ao imaginário.

Para $\mathrm{Abril}^{2}$, um texto não é certamente uma construção estritamente verbal, nem um todo a ser compreendido por suas propriedades internas. 'Texto', como unidade de um processo de comunicação, é sempre uma construção semiótica complexa, na qual estão presentes diferentes linguagens e cuja existência é fortemente vinculada às redes textuais. Diz Abril, nesse sentido: "En esas redes textuales se establecen relaciones diversas entre cada texto particular y el conjunto en que lo insertamos o hallamos inscrito: se trata unas veces de la relación parte/todo, como la que imputamos la 'pertenencia' de un texto literario o pictórico a esos conjuntos a los que, respectivamente, denominamos 'literatura' o 'pintura'. En otras ocasiones se trata de una relación local/global, cuando [...] se produce en escalas muy diversas: la relación de la obra particular con la obra completa de un autor, de una colección o recopilación, de una época, etc. Y, en fin, sin pretensiones de completar una enumeración exhaustiva, también hallamos relaciones entre texto interpretante/interpretado, como las que se dan entre los textos 'críticos' o citacionales y aquellos otros que constituyen su objeto. Sin olvidar que los metatextos críticos devienen históricamente textos-objetos para nuevos metatextos”2 (p. 47).

Um texto, portanto, é parte de uma engrenagem, de uma prática sociodiscursiva e cultural e nunca pode ser tomado como uma unidade isolada ou encapsulada em si mesmo: porque se origina de outros textos, porque se referencia, se projeta em outros textos, porque é apreendido a partir do repertório textual, social e historicamente constituído, que cada um maneja ao interagir com ele. Nessa perspectiva, um 'texto' pode ser chamado de 'visual' não porque é exclusivamente imagético, mas porque sua inserção nessas várias redes textuais privilegia materiais que acionam um repertório visual. Trata-se, assim, de um 'predomínio', não de uma suposta pureza.

Na dinâmica social dos textos, necessariamente multimodais, Abril reserva o termo imagem para caracterizar um processo perceptivo tipicamente vinculado ao imaginário, como a capacidade historicamente situada de perceber e apreender o mundo. Para Abril, “[...] las imágenes no son necesariamente visuales y porque 
en el caso de los textos visuales gran parte de lo que llamamos 'imagen' es ajeno a lo visible, o netamente invisible, aunque se relacione necesariamente con/por medio de la visualidad”2 (p. 65). Isso é dizer então que uma 'imagem' é o que resulta da interação com diferentes textos, não só os visuais, e depende de um conjunto de crenças, desejos, repertórios, saberes, que mobilizamos em circunstâncias específicas. Como se vê, o pesquisador espanhol desloca a noção de imagem de uma superfície semiótica e de um imanentismo e a insere numa dinâmica social de percepção e conhecimento.

Esse conjunto de deslocamentos - terminológicos e conceituais - implica também uma concepção peculiar da relação entre visualidade, visibilidade e invisibilidade. O 'visual', o que 'se entende', 'se apreende', tem uma íntima conexão com o conhecer e o perceber, pois nele estão articulados tanto o que se se vê quanto o que não se vê. Na esteira de reflexões instauradas por Merleau-Ponty, Abril ${ }^{2-3}$ afirma que tudo o que se vê está sempre e necessariamente dependente do que não se vê, constituído por relações de desejo (o que se quer ver), epistêmicas (o que se sabe e/ou que se crê) e pragmáticas (o que se faz com o que se vê). É precisamente essa interdependência processual e conjuntural entre visível e invisível que conforma a visualidade.

Um exemplo pode ser útil aqui. Imaginemos uma pessoa entrando numa sala que está completamente vazia, com exceção de uma cadeira disposta no meio do ambiente. Ao perceber a sala e a cadeira, a observadora age na direção de compor um texto visual (que forma em sua mente, através de seu olho) que evoca todo um repertório de outros textos que a auxiliam a perceber a cena e a compor uma apreensão do mundo, para o qual contribuem os sons (ruídos e silêncios, por exemplo), cheiros (proeminentes ou ausentes) e possíveis marcas identificáveis e legíveis. Esse texto visual é, portanto, fruto não apenas de um ato mecânico de percepção, mas de um olhar socialmente instituído e cujos sentidos que emergiram conectam visualidade e imaginário. Se esse observador entende que 'todos já se foram' ou que a sala é um 'lugar desolado' ou ainda que 'aqui está um bom lugar para estudar', esses entendimentos dependem de saberes, crenças, desejos e intenções que articulam o texto visual a modos de saber e fazer, promovendo a visualidade da cena e inserindo-a em imaginários cognoscíveis e atualizáveis.

Discutido por Leal ${ }^{4}$, Leal e Carvalho ${ }^{5}$, Leal e Mendonça ${ }^{6}$ e Antunes, Mafra e Jáuregui ${ }^{7}$, entre outros, perspectivas como as de Abril ${ }^{2-3}$ ao mesmo tempo explicitam, defendem e afirmam a instabilidade do texto, que passa, então, na sua articulação com o olhar, a visualidade e o imaginário, a ser entendido não como um todo fechado e circunscrito, mas como uma 'textualidade', ou seja, como um processo aberto e inevitavelmente instável. Tomamos algo como 'texto' à medida que ele emerge em meio a um conjunto de relações diversas e esse ‘produto’ é assim efêmero, nos ritmos e (des)compassos dessas interações.

\section{Textualidades periódicas}

Na cobertura brasileira de casos de violência contra a mulher cis e heterossexual, não é incomum encontrarmos textos como os apresentados nas Figuras 1, 2 e 3. 


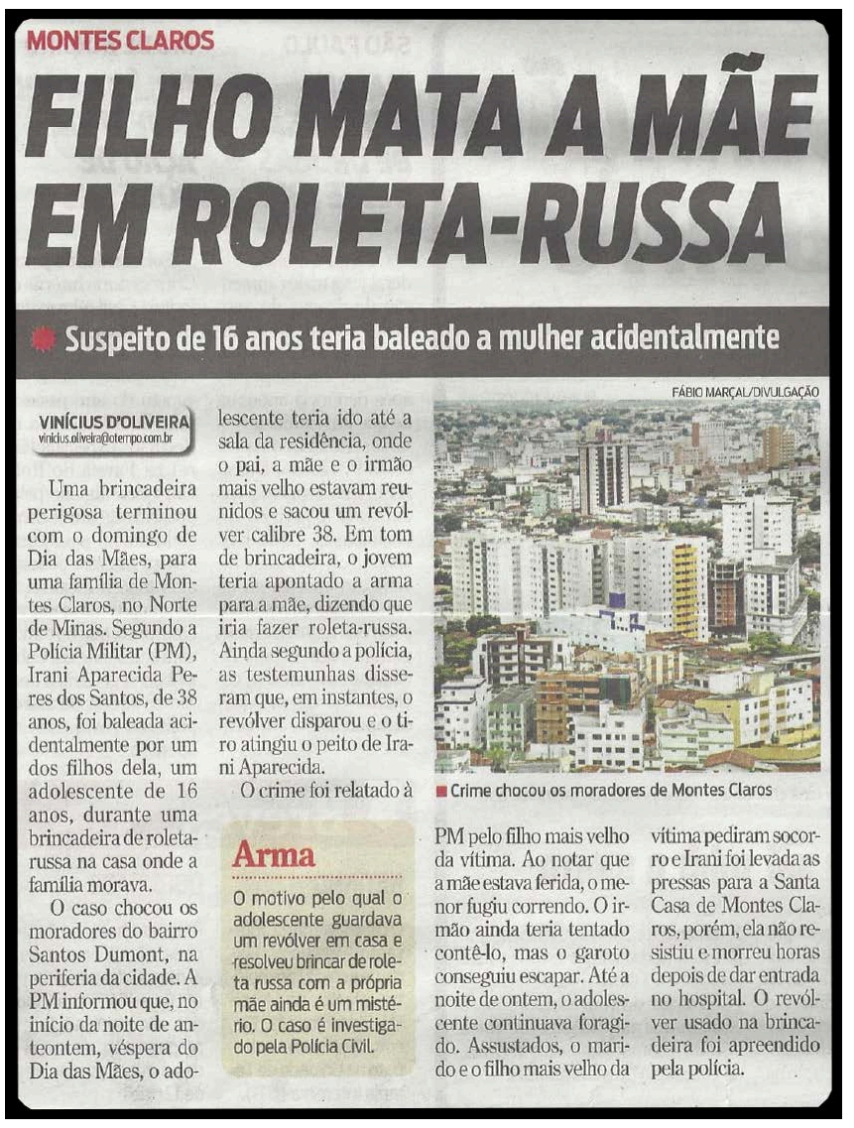

Figura 1 - Notícia jornal SuperNotícia

Fonte: D'oliveira ${ }^{8}$.

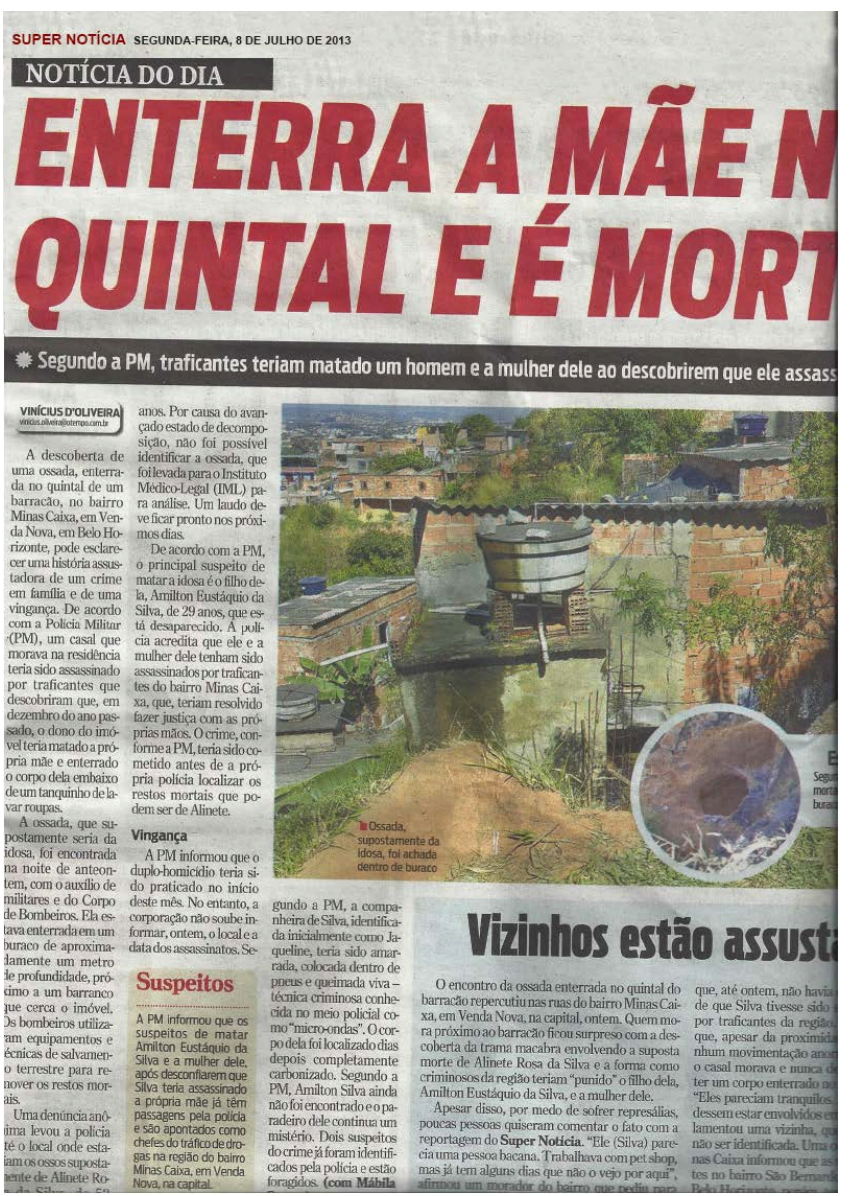

Figura 2 - Página do SuperNotícia

Fonte: D'oliveira9?. 


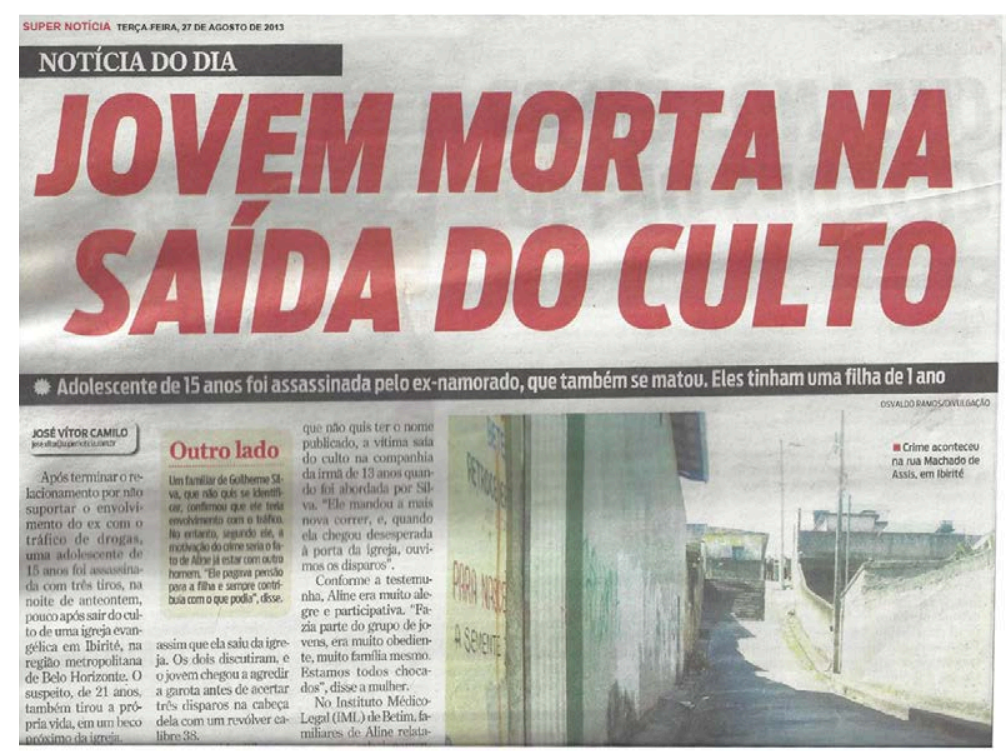

Figura 3 - Página do SuperNotícia

Fonte: Camilo ${ }^{10}$.

Nessas três reproduções, extraídas do 'SuperNotícia', o jornal popular mais vendido no país, temos casos de mulheres assassinadas por pessoas com as quais tinham relações afetivas (filhos ou ex-namorado). A narrativa verbal apresenta as histórias dos crimes e as páginas do jornais são compostas ainda por três fotografias: uma delas, com uma visão do alto da cidade de um dos crimes; outra de um quintal de uma casa, e a terceira de uma rua de um bairro pobre. Nos três casos, as fotografias pouco dizem sobre os crimes e seus personagens principais (vítimas, agressores, investigadores, testemunhas etc.), pois trazem apenas cenários genéricos, que podem ser associados a diferentes lugares do Brasil e mesmo da América Latina. Tomadas isoladamente, essas três fotografias são uma espécie de enigma: o que fazem elas ali? São meras ilustrações? Indicam precariedade das condições de produção do jornal? São materializações de escolhas editoriais equivocadas?

A partir da terminologia de Abril, podemos, porém, perguntar antes: qual é o 'texto' aqui? Cada foto integra uma página na qual estão presentes signos gráficos e verbais, e esse conjunto compõe o que jornalísticamente é chamado de 'notícia', uma modalidade textual marcadamente narrativa. A história é contada principalmente pelos signos verbais, e os demais (gráficos e fotográficos) auxiliam na visualidade do que é narrado e o ancoram em espaços distintos: na página do jornal e no espaço urbano brasileiro. Na direção contrária, a história verbal, por sua vez, também ancora os demais elementos semióticos. Assim, de início, já percebemos que, mais do que 'ilustrações', as fotografias são parte de um texto verbograficovisual que emerge à medida que 'lemos' o jornal e não podem ser tomadas isoladamente.

A pergunta, consequentemente, passa a ser, então, sobre o olhar que se dirige a esse texto verbograficovisual. Dificilmente ele será ingênuo, 'virgem', pois se dirigirá à página já conhecendo aquele jornal, jornais de modo geral, outros crimes, outras histórias, outros cenários. Ao colocarmos as reproduções das páginas em sequência, aqui, sugerimos inclusive uma espécie de novo texto, composto por sua vez de diferentes páginas, temporalmente distantes. Esse outro texto poderia ser aquele que um leitor habitual do jornal teceria, caso interessado em casos semelhantes ou sensível à sua recorrência. Nessa perspectiva, uma vez que parece ser frequente a presença de paisagens na composição dos textos jornalísticos sobre violência contra mulher, podemos modificar nossas perguntas. A primeira delas vem a ser sobre a visualidade que cada texto (cada página) assim como o texto mais amplo (as três páginas e outras semelhantes) promovem sobre um grave problema social. E mais: que relações de visibilidade e invisibilidade perpassam essa visualidade?

Ao pesquisarmos os dados de crimes de ódio praticados contra pessoas LGBTQ+, entre os anos de $2015 \mathrm{e}$ 2017, percebemos traços comuns nos modos pelo quais são produzidos os textos verbovisuais que noticiam esses crimes. Comparados tanto na versão impressa quanto na versão digital, reconhecemos que os jornais promovem um diálogo dramático entre os textos verbais e visuais. Essa estratégia de produção textual acentua de forma considerável as condições do acontecimento. O texto verbal quase sempre narra o cotidiano da vítima, localiza-a em um contexto social e explora detalhadamente as condições do crime. Os elementos 
dramáticos são reforçados pela cena registrada no texto visual. A página reproduzida na Figura 4 exemplifica o que poderíamos chamar de um 'modo clássico' da cobertura desse tipo de crime. Diferentemente do crime contra as mulheres, o corpo ferido está quase sempre presente nas fotografias. Porém, ele é representado de modo fragmentado, como se o texto visual deixasse escapar um resto imagético, um traço gráfico que se amplia na narrativa verbal. As condições do corpo (local onde se encontra, situação e posição, vestido ou desvestido, objetos pessoais presentes na cena) dão conta da sucessão de acontecimentos trágicos da existência relatada. Uma primeira inferência possível sobre essas narrativas se dá na relação texto/leitor. Ao que nos parece, o jornal integra um fluxo visual fortificado por valores excludentes de certa parte da população, investe no jogo visível/invisível no qual a visibilidade criada é resultado de um movimento político mais amplo, que despende energia na manutenção constante dos processos de invisibilidade destas pessoas a partir de lógicas de preterição moral e social ${ }^{11}$. Ao tentar operar a par e passo com uma 'pretensa experiência' do coletivo de leitores, o jornal visibiliza as baixas condições de cidadania da vítima. Um corpo sem direitos básicos fundamentais. Tal tática textual se comprova na negação do nome social e na apresentação do nome civil. A insistência na presença do nome civil é uma maneira de humilhação e de negação da identidade ${ }^{\text {iv }}$.

\section{Metrópoles}

\section{Travesti é torturada e morta a pedradas em Fortaleza}

De acordo com as autoridades, o caso está sendo investigado e o processo se encontra "bastante adiantado". Um dos homens já teria sido preso

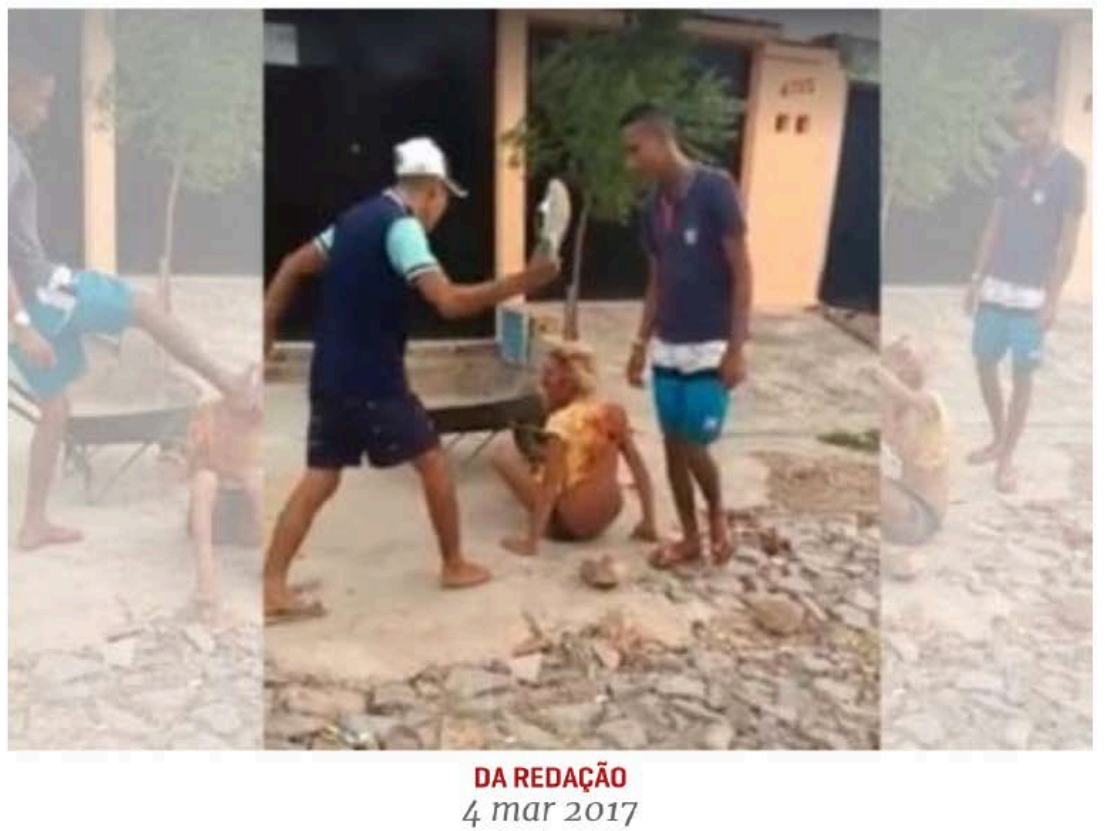

Figura 4 - Frame de vídeo publicado por agressores Fonte: Redação ${ }^{13}$.

iv "[...] encontramos nessa ação o gesto punitivo, o julgamento que sentencia a pessoa a permanecer na clausura do gênero/ sexo assignado no nascimento impedindo que ela ou ele se apresente socialmente com o nome correspondente ao gênero com que se identifica. Nominar não é algo simples. O nome determina, individualiza e localiza a pessoa na sociedade. O nome também determina o gênero. É através do nome que somos conhecidos no grupo social. Nesse sentido, é fundamental ressaltar que nome social não é apelido. Um nome social designa a identidade de gênero de quem o escolheu, delimita as formas de apresentação e relacionamento social. O reconhecimento do nome social afirma, para pessoas trans e travestis, a dignidade como pessoa"12. 
A visibilidade que se produz, nestes casos, investe na crença da morte como uma sequência no drama que é a vida da vítima, como consequência de uma vida indigna. Entre o anos de 2016 e 2017, segundo as estatísticas do relatório de pesquisa realizada pelo Grupo Gay da Bahiav , houve um crescimento de 30\% no número de casos de violência seguida de morte contra a população LGBTQ+ no Brasil. A cada 19 horas uma pessoa LGBTQ+ é morta ou se suicida no país. No ano de 2000 eram 130 casos registrados. Em 2017, o número cresceu para 445 pessoas que chegaram a óbito devido a atos de violência pela não aceitação de sua identidade de gênero ou orientação sexual. Uma pessoa trans ou travesti é expulsa de casa por volta dos 13 anos e, geralmente, é excluída do ambiente escolar, discriminada pelo sistema de saúde e rejeitada pelo mercado de trabalho. No caso da população trans e travesti, a média de idade das vítimas é de 27 anos. Segundo os dados da pesquisa de violência contra pessoas trans e travestis no Brasil, estudo realizado pela Associação Nacional de Travestis e Transexuais (Antra) ${ }^{v i}$, cerca de 70\% dos assassinatos foram praticados contra profissionais do sexo e $55 \%$ dos crimes aconteram nas ruas. Esses dados são importantes para pensarmos como se constitui o imaginário social sobre esse público, como lembra Moraes: "O imaginário social é composto por um conjunto de relações imagéticas que atuam como memória afetivo-social de uma cultura, um substrato ideológico mantido pela comunidade. Trata-se de uma produção coletiva, já que é o depositário da memória que a família e os grupos recolhem de seus contatos com o cotidiano. Nessa dimensão, identificamos as diferentes percepções dos atores em relação a si mesmos e de uns em relação aos outros, ou seja, como eles se visualizam como partes de uma coletividade"14.

Para além da lógica que afirma a cobertura jornalística desses crimes como uma outra forma de morte da vítima, acreditamos que a duração existente no texto visual é um fator a ser considerado nesse tipo de crime. Os corpos e as violências registradas na fotografia jornalística ampliam e propagam os valores do crime de ódio. O crime de ódio contra LGBTQ+ é um crime para ser visto, para ser propagandeado: "A luz das considerações de Abril sobre os textos visuais, podemos pensar que os corpos de pessoas homossexuais, trans e travestis, muitas vezes, quando mortos têm maior poder de fala nos meios de comunicação e informação do que quando estão vivos. Pelas páginas circulam textos visuais de corpos sentenciados. $\mathrm{O}$ ato violento que humilha, fere e ceifa a vida é consequência de um julgamento. Em todo julgamento há uma autoridade judicante que forma um juízo. $\mathrm{O}$ agressor chama para si esta autoridade para justificar suas atitudes. Tais atitudes representam a 'honra' da normatividade lavada com sangue. Porém, a sentença não deve ficar retida aos limites do tribunal, ele precisará ser promulgada em público. Para isso, a morte deve ser espetacularizada. O corpo é transformado no lugar do acontecimento julgamento/sentença. Uma morte espetáculo, praticada sob um ponto de vista, um ritual onde o corpo sacrificado é exposto para servir de lição. Uma população destinada à morte na via pública, uma gente que não importa em vida”的.

Pensar a imagem dos crimes de ódio contra a população LGBTQ+ como espetáculo só é possível diante do reconhecimento da dimensão política da cultura visual. Tal dimensão 'pedagogiza' os modos de ver, estabelece condições para a interpretação dos textos verbovisuais e negocia com as memórias visuais. Temos por pressuposto que as páginas, impressas e digitais, dos jornais são textualmente organizadas sob lógicas políticas e sociais, articuladas sob intencionalidades específicas e, portanto, perpetuadoras de valores. Um texto está sempre conectado a redes textuais diversas, a imaginários os mais distintos. Na chamada cobertura jornalística policial, o registro fotográfico do assassinato não permite que o corpo morra. Ainda que sem vida, no texto visual ele é compelido a comunicar, via à exibição de seu martírio, de seu julgamento e de sua sentença de morte.

\footnotetext{
v Disponível em: http://www.ggb.org.br

vi Disponível em: www.antra.org.
} 


\section{Instabilidades}

Ao aproximarmos os modos como jornais brasileiros narram e produzem a visualidade de violências contra a mulher cis e heterossexual e contra pessoas LGBTQ+, observamos, como dissemos, modos sugestivamente dissonantes. Por um lado, construções contidas, textos visuais vagos e genéricos; por outro, narrativas de sangue. Tais diferenças certamente se articulam às especificidades das relações de gênero e de sexualidade referentes às mulheres e às pessoas LGBTQ+. Mas elas explicitam também dinâmicas peculiares de visualidade, assentadas nas articulações entre visibilidade e invisibilidade. Poder-se-ia dizer, nesse sentido, que, no caso das mulheres cis e heterossexuais, a presença de fotografias de paisagem indicaria um gesto de 'invisibilização' e no caso dos LGBTQ+, de modos - grotescos, possivelmente - de 'visibilidade'. Quando tomamos como referência a terminologia de $\mathrm{Abril}^{2}$, porém, esse diagnóstico aparentemente óbvio se mostra um tanto mais complexo. Em ambas as situações, como dissemos, temos violências desenvolvidas a partir de matrizes históricas de configurações das relações de gênero e sexualidade. No entanto, por que os corpos de mulheres cis e heterossexuais podem ser ocultados, não 'precisam' ser mostrados, e os de LGBTQ+ são explorados em sua fisicalidade? Se tomamos o invisível como um conjunto de crenças e saberes, que condiciona a percepção, em articulação com o imaginário, as respostas surgem como potencialmente provocadoras.

Ao associarem os crimes contra as mulheres cis e heterossexual às paisagens urbanas, os textos jornalísticos afirmam sua cotidianidade, provendo sua visibilidade a partir do comum, do regular. Não há espanto ou excepcionalidade. Como observa a vasta literatura sobre violência contra a mulher ${ }^{16-24}$, as formas mais letais e fisicamente visíveis de agressão se situam numa espécie de continuum composto por constrangimentos simbólicos diversos (morais, sexuais, psicológicos, patrimoniais etc), todos de caráter cotidiano e 'rotineiro'. A invisibilização dos corpos, nesse sentido, é mais um componente dessa construção, desse modo de reconhecer e saber a violência contra a mulher cis e heterossexual como algo ordinário. A visualidade que resulta, nesse caso, é da ordem de uma indiferença cotidiana: é mais um caso, mais uma morte, sem mais problemas ou questões. A presença de sangue e de corpos machucados de pessoas LGBTQ+, por sua vez, traz esse componente excepcional e, ao mesmo tempo, retira as vítimas do cotidiano, da ordem do humano. Afinal, como apontam Borillo ${ }^{25}$, Eribon ${ }^{26}$ entre outros, a homofobia (assim como a lesbofobia, a transfobia e outras formas de discriminação) retira ou exclui do comum, do humano compartilhado, seres e corpos postos como objetos de escárnio e vistos como inferiores, estranhos, bizarros etc. As pessoas LGBTQ+ assassinadas podem assim ser apreendidas pelos jornais como corpos tornados monstros, e a visualidade que resulta acentua esse caráter inumano, grotesco, bizarro. Se os dois gestos se estabelecem por caminhos distintos, eles se aproximam então na desumanização das vítimas, ora vistas como indiferentes ora como monstruosas. Nos dois casos, a visualidade, como apontamos, tem um explícito componente político.

Organizadas sob rígidos padrões hierárquicos, dotadas de atributos que evidenciam sua presença e servem de modelos para aqueles que virão, as masculinidades se afirmam também no invisível. As normas das masculinidades controlam os papéis de gênero ${ }^{27}$. Essas normas agrupam regras conformadoras do gênero masculino: todos os homens devem obter êxito profissional; praticar atos heroicos que demonstrem suas destreza, coragem e força; conter as próprias emoções e ser um porto seguro para quem se desequilibra; ser autoconfiante e exercer liderança etc ${ }^{28}$. Entretanto, as masculinidades envolvem, especialmente, a virilidade. Tal característica revela-se para além do másculo como atributo físico. Ela é reconhecível, também, nos atributos psicológicos do macho humano. No senso comum, o ser viril foi significado como o bom reprodutor. Porém, o viril também foi compreendido como o violento, associando e naturalizando a conexão entre as masculinidades e as violências. Nesse sentido, a violência estaria entre os papéis do gênero masculino, como um direito, como algo não só permitido como pressuposto. Há uma vigilância sobre os corpos dos machos humanos que acompanha sua realização como homem/masculino. A ausência 
da violência no masculino o associa ao feminino. Essas formas de controle se revelam na materialidade dos corpos, seja nas formas de expressão e gestuais, seja nos modos de exercer uma força vertical e desigual sobre outro corpo e nas construções simbólicas. O masculino é ao mesmo tempo causa e consequência da violência.

Com origem estadunidense nos anos de 1970, os estudos responsáveis por correlacionar o uso da linguagem e os limites do gênero social ${ }^{29}$ demonstram a intensa participação do primeiro nos territórios do segundo. A associação entre gênero e linguagem é continua, mas não uniforme. Ela se manifesta de maneira particular em dadas situações. No caso das fotografias jornalísticas aqui analisadas percebemos a operação simbólica compartilhada/construída em dois sentidos: o homem e seu direito de praticar a violência contra os corpos das mulheres cis e heterossexuais, o homem e o seu dever de denunciar os corpos que escapam às construções regulares de gênero e sexualidade, como aqueles que, portando a genitália 'masculina', se recusaram a ser machos. Em todos os casos, a mídia opera como um simbolizador. A não exposição nas matérias que relatam a violência doméstica do corpo violentado das mulheres cis e heterossexuais, optando por utilizar imagens vagas do espaço público, perpetua a ideia da violência como direito e prática regular da masculinidade. Contrariamente, a exposição dos corpos das mulheres trans e travestis violentadas e mortas no espaço público indica o julgamento da masculinidade, a sentença de morte e a execução pública. A edição jornalística destes crimes, o modo pelo qual eles são transformados em textos verbovisuais, participa enfaticamente dos jogos simbólicos de violência.

No entanto, nem a visualidade, nem a invisibilidade, nem a visibilidade ou sequer o texto são dados estáveis. Assim, as leituras que acabamos de fazer são algumas entre uma miríade de possibilidades. Se as entendemos como relações, de caráter pragmático e situadas na cultura e na história, os modos como elas emergem serão sempre dependentes de um conjunto variável e instável de fatores, que necessariamente implicam quem consome essas narrativas e os modos como imaginários são atualizados. Isso não é retirar o componente político da cultura visual, mas, ao contrário, torná-lo um problema. Se a dimensão política do visível e da visualidade podem ser mais reconhecíveis, a terminologia de Abril explicita sua importância no que ele chama de invisível do texto visual. Na perspectiva de Abril, o invisível, como dissemos, não é o ausente, mas um conjunto de relações epistêmicas, pragmáticas e intencionais que conformam o que é visto, sabido e percebido. Há, portanto, uma íntima conexão entre o invisível e o imaginário. As narrativas jornalísticas, ao organizarem o que mostram, o que tornam visível, o fazem atualizando um repertório de saberes e imagens sobre violência, sobre as relações de gênero, sobre as mulheres cis e heterossexuais e sobre as pessoas LGBTQ+. Há algo que não precisa ser dito, porque já sabido, já pressuposto, porque, invisível e presente, dá sentido ao que é ofertado ao nosso olhar. A dimensão política da cultura visual, ao nosso ver, se apresenta portanto como relações complexas e instáveis, não se resumindo à explicitação de um componente ideológico ou de relações de poder. Ela exige uma contínua interrogação acerca do que nos envolve e de nós mesmos.

\section{Referências}

1. Preciado PB. Manifesto contrassexual. São Paulo: Editora N-1; 2017.

2. Abril G. Cultural visual, de la semiótica a la política. Madrid: Plaza y Valdés; 2013.

3. Abril G. Analisis críticos de textos visuales. Madrid: Paidós; 2007.

4. Leal B. Do texto à textualidade na comunicação: contornos de uma linha de investigação. In: Leal $B$, Carvalho C, Alzamora G, organizadores. Textualidades midiáticas. Belo Horizonte: PPGCOM UFMG; 2018. v. 1 , p. $17-34$.

5. Leal B, Carvalho, C. Aproximações à instabilidade temporal do contexto. R Famecos Mídia Cult Tec. 2017 [citado em 2019 maio 24]:24(3):1-17. Disponível em: https://bit.ly/2K053PH doi: http://dx.doi. org/10.15448/1980-3729.2017.3.27042 
6. Leal B, Mendonça C. Verlas a ellas: mujeres trans y dimensiones políticas de la cultura visual. In: Leal B, Carvalho C, Alzamora G, organizadores. Textualidades midiáticas. Barcelona: Editorial UOC; 2017. v. 1 , p. $119-30$.

7. Antunes E, Mafra R, Jáuregui C. Mídia em trânsito, mídia em transe: textualização, epifania e distanciação. In: Leal B, Carvalho C, Alzamora G, organizadores. Textualidades midiáticas. Belo Horizonte: PPGCOM UFMG; 2018. v. 1, p. 35-57.

8. D'oliveira V. Filho mata a mãe em roleta russa. Jornal SuperNotícia. 2013 maio 12:p.3.

9. D'oliveira V. Enterra a mãe no quintal e é morta. Jornal SuperNoticia. 2013 jul. 06:p.5

10. Camilo JV. Jovem morta na saída do culto. Jornal SuperNotícia. 2013 out. 27: p.3

11. Butler J. Problemas de gênero: feminismo e subversão da identidade. Rio de Janeiro: Civilização Brasileira; 2015. (Sujeito \& história).

12. Mendonça $C$. O nome social nas organizações educativas: diminuição da vulnerabilidade via a promoção de direitos. In: Marques A, Lima F, Oliveira IL, Reis D. Comunicação organizacional: vertentes conceituais e metodológicas. Belo Horizonte: PPGCOM UFMG; 2017. p.223-30.

13. Redação. Travesti é torturada e mota a pedradas em Fortaleza. Metrópolis [Internet]. 2017 [citado 2017 maio 24]. Disponível em: https://www.metropoles.com/brasil/travesti-e-tortuada-e-morta-a-pedradasem-fortaleza

14. Moraes D. Imaginário social e hegemonia cultural [Internet]. Juiz de Fora: Acessa.com mais Comunicação; 2012 [citado em 2019 maio 24]. Disponível em: https://bit.ly/2HUx1JS

15. Mendonça C. Corpos na pista: textualização no assassinato de pessoas homossexuais, trans e travestis. In: Martins M, Vaz PB, Correia ML, Martins ML. Sentidos da morte na vida da mídia. Curitiba: Appris, 2017. p.165-76.

16. Sagot M. Ruta crítica de las mujeres afectadas por la violencia intrafamiliar en América Latina: estudios de caso de diez países. Washington: Organización Panamericana De La Salud; 2000.

17. Mourão BM. Violência contra a mulher: conceito válido? In: Ratton JL, Lima RS, Azevedo RG, editores. Crime, polícia e justiça no Brasil. São Paulo: Contexto; 2014. p. 285-96.

18. Pasinato W. "Femicídios" e as mortes de mulheres no Brasil. Cad Pagu. 2017 jul.-dez.;37:219-46.

19. Pasinato W. Violência contra a mulher: segurança e justiça. In: Ratton JL, Lima RS, Azevedo RG, editores. Crime, polícia e justiça no Brasil. São Paulo: Contexto; 2014. p. 277-84.

20. Soares BM. A 'conflitualidade' conjugal e o paradigma da violência contra a mulher. Dilemas R Est Conf Contr Soc. 2012; 5(2):191-210.

21. Vasconcellos FB. Delitos de proximidade e violência doméstica. In: Ratton JL, Lima RS, Azevedo RG, editores. Crime, polícia e justiça no Brasil. São Paulo: Contexto; 2014. p. 293-8.

22. Portella AP, Ratton, JL. A teoria social feminista e os homicídios: o desafio de pensar a violência letal contra as mulheres. Contemporânea. 2015;5(1):93-118.

23. Leal B, Carvalho C, Antunes E. Violence against Brazilian women in public and mediatic spheres. Comunicar. 2018;26:19-27.

24. Soares J, Trindade V, Viero F, organizadores. Dar a ver: textualidades, gêneros e sexualidades em estudos em comunicação. Belo Horizonte: PPGCOM UFMG; 2018.

25. Borrillo D. Homofobia: história e crítica de um preconceito. Belo Horizonte: Autêntica; 2010.

26. Eribon D. Reflexões sobre a questão gay. São Paulo: Cia de Freud; 2008.

27. Wittig M. El pensamento heterossexual y otros ensayos. Madrid: Egales; 2001.

28. Connel RW. Masculinites. 2nd ed. California: University of California Press; 2005.

29. Lakoff R. Language and women's place. New York: Harper and Row; 1975. 